\title{
Comparative Study on Growth and Economic Performances of Nile Tilapia, Oreochromis niloticus Reared Under Different Culture Enclosures in Akure, Nigeria
}

\author{
Oluwalola Oluwatuyi Ifedayo ${ }^{1, *} \mathbb{C}^{-}$, Fagbenro Oyedapo Adewale ${ }^{1}$, Adebayo \\ Olabode Thomas ${ }^{1}$
}

${ }^{1}$ Federal University of Technology, Department of Fisheries and Aquaculture Technology, P.M.B 704, Akure, Ondo State, Nigeria

\section{Article History}

Received 24 May 2020

Accepted 26 August 2020

First Online 01 September 2020

\section{Corresponding Author}

Tel.: +2348030450957

E-mail: tuyioluwalola@yahoo.com

\section{Keywords}

Growth performance

Economic performance

Culture Enclosures

Oreochromis niloticus

\begin{abstract}
This study was conducted to determine the growth and economic performances of Nile Tilapia Oreochromis niloticus reared in different culture enclosures in Akure. 900 O. niloticus fingerlings (mean weight $8.30 \pm 0.06 \mathrm{~g}$ ) were acclimatized for 24 hours, out of which one hundred fingerlings were randomly selected and distributed into the three prepared culture enclosures (plastic tanks, sandcrete tanks and earthen ponds) of the same size $(3.0 \mathrm{~m} \times 2.8 \mathrm{~m} \times 1.0 \mathrm{~m})$. Each treatment was in triplicates. The fingerlings were fed with formulated standard diet of $30 \%$ crude protein at $5 \%$ body weight. Fish were fed twice daily for 185 days. The total yield of fish was significantly greater $(P<0.05)$ in earthen pond, $1.93 \mathrm{~kg}$ than those in sandcrete $1.47 \mathrm{~kg}$ and plastic tanks $1.42 \mathrm{~kg}$. There was significant difference $(P<0.05)$ in final weight gain, feed conversion ratio, mean daily weight gain between $O$. niloticus fingerlings stocked in the three culture enclosures. Fish in earthen pond had the highest weight gain $(135.9 \mathrm{~g})$ and specific growth rate $(1.54 \%)$. There was significant difference $(P<0.05)$ in the Net profit obtained and benefit cost ration for the three culture enclosures. The study considered earthen pond to be more productive and the most ideal culture enclosure for growth optimization of $O$. niloticus
\end{abstract}

\section{Introduction}

Nile tilapia (Oreochromis niloticus) is a cichlid fish native to Africa. It has been successfully farmed under a wide range of environmental conditions and is an important aquaculture fish species in many parts of the world, particularly in tropical and sub-tropical countries (El-Sayed, 2006; Dagne et al., 2013). It is considered to be one of the most productive and internationally traded food fishes in the world (Chakraborty and Benerjee, 2012; Hernandez et al., 2013; Siddik et al., 2014). In recent years, attention has been focused on developing tilapia culture. The production of farmed tilapia in the world is rising, and production of it reached 6,510,700 tons in 2017 (FAO 2018). In Nigeria tilapia is one of the most important cultured fish. Today, $O$. niloticus has become the shining star of aquaculture with many farms beginning and others expanding as consumption rate increases across the globe (Fitzsimmons, 2005; Ogello et al., 2014). The success of $O$. niloticus is related to the fact that it grows and reproduces in a wide range of environmental conditions, has a low trophic level for feeding and tolerates stress induced by handling and poor water quality (Liti et al., 2005; Tsadik and Bart, 2007; Dagne et al., 2013).

Fish, a major product of aquaculture is an important source of protein for the teeming population in developing nations (FAO, 2018). Fish and fishery products play a critical role in global food security and the nutritional needs of humans' health (FAO, 2018). Globally, fish account for about $20 \%$ of intake of animal protein (FAO, 2018). This share, however, can exceed $50 \%$ in some countries (FAO, 2018). In West African coastal countries, where fish has been a main source of 
local diets, the proportion of dietary proteins that comes from fish is very high. Fish account for more than $60 \%$ protein intake in Nigeria (Adekoya and Miller, 2004), $43 \%$ in Senegal, $72 \%$ in Sierra Leone, and 55\% in Gambia and Ghana (FAO, 2013). The same variation in percentage is also seen for some Asian countries and small Island states, where the contribution from fish as protein source is also significant. In Maldives, fish contributes up to $70 \%$ of dietary protein, $60 \%$ in Cambodia, 57\% in Bangladesh, 54\% in Indonesia and $55 \%$ in Sri Lanka (FAO, 2013). Aquaculture is one of the fastest growing food-producing sectors in aquatic field and is set to play a key role in meeting the rising demand for fishery products due to increase in human population and decline natural fisheries resources (FAO, 2018). One of the priorities of aquaculture is the increase in the production of fish that will meet the demand of the increasing population. Nigeria, like many other developing countries of the world is faced with the task of meeting the protein demands of its everincreasing human population (Tijani, 2004). World Fish Centre (2003) observed that total catches of fish from the wild reached a plateau in the early 1990s. Capture fishery production for both food and non-food utilization has leveled off. FAO (2012) also reported that the maximum wild capture fisheries potential from the world's oceans has probably been reached. Fish is a cheap source of animal protein and has no religious taboo or any known cultural limitation affecting it's consumption, therefore increasing the aquaculture production in Nigeria is clearly needed, especially as the capture fisheries resources are declining, due to over fishing, habitat destruction and pollution (Olaoye et al., 2014). Fish farming is an enterprise, thereby proper management techniques and economics must be put in place. Fish farming/culture is the growing of fish in a controlled environment (concrete or earthen ponds), vats (wooden or fibreglass) and plastics (Osawe, 2007; Nwokoye et al., 2007). There's need for the expansion of aquaculture and improvement in aquaculture output. The objective of the study was to determine the most productive culture enclosures for the production of Oreochromis niloticus. Ponds are the most widely used structures for aquaculture production. In Africa, especially in Nigeria, the species mostly cultured are Clarias gariepinus, Heterobranchus $s p$. and their hybrids (Adewolu et al., 2008). The culture of fish in plastic and concrete tanks is now a common practice in Nigeria. Homestead fish farmers operate in concrete tanks whose sizes and shape vary from location to location depending on individual taste, availability of space and financial resources (Omitoyin, 2007).

There are various enclosures used to raise fishes such as unused canoes, plastic and depressions that can hold water, tanks and earthen ponds (Angahar, 2017). Over the years, several people including government have always emphasized the need to increase fish production as priority without due consideration to the particular type of production environment in which to invest, with particular reference to profitability and economic analysis of the concrete, plastic and earthen pond methods. A basic requirement of an investment decision is to be acquainted with the best system which can give the maximum profit to resource use. The type of culture medium used and their management have a significant influence on fish profitability (Ross and Waten, 1995). Therefore, the need arises to determine the best production system for fish production with good operating strategy to optimize fish farm profitability and productivity

\section{Materials and Methods}

\section{Experimental Procedure}

This study was conducted at the Teaching and Research Farm of the Department of Fisheries and Aquaculture Technology, Federal University of Technology, Akure, Ondo State for a period of six months.

Nine hundred Oreochromis niloticus fingerlings (mean weight $8.30 \pm 0.06 \mathrm{~g}$ ) are purchased from a reputable fish farm in Ondo State, Akure and were transported in 50 litre plastic kegs to the Teaching and Research Farm of the Department of Fisheries and Aquaculture Technology, Federal University of Technology, Akure, Ondo State.

The fishes were acclamatized for $24 \mathrm{hrs}$ prior to commencement of the studies to allow for digestion of food already eating and prepare the stomach for the formulated feed. One hundred fingerlings (mean weight $8.30 \pm 0.06 \mathrm{~g}$ ) were randomly selected and stocked in three prepared different culture enclosures: Plastic tanks, Sandcrete tanks and Earthen ponds of the same size (3.0M X 2.8m X 1.0m) labelled as T1, T2 and T3 respectively. Each treatment was in triplicates. The culture facilities were filled with water up to $3 / 4$ in all the treatment. The fingerlings were fed with formulated standard diet as reviewed by Fagbenro and Adebayo (2005) in Table 1. Feeding was carried out at 09:00 and 16:00 hours for 185 days. Changing of water in plastic and sandcrete tanks culture facilities was done on a weekly basis.

Water quality parameters (Temperature, $\mathrm{pH}$, Dissolved Oxygen, nitrates and nitrites) were determined on a weekly basis during the experimental period. Temperature readings were taken weekly on the farm using Mercury-in-glass thermometer, $\mathrm{pH}$ and DO were determined using $\mathrm{pH}$ meter (MODEL, Mettler Toledo 320) and dissolved oxygen meter (DO Model, 9071), nitrates and nitrites were determined by using Analytical Profile Index (API) test kits.

Data collected on growth performance were determined using the following parameters:

- Initial mean weight $(\mathrm{g} / \mathrm{fish})=$ Initial weight of fish $(\mathrm{g})$ Number of fish stocked 
Table 1. Gross composition of the formulated standard diet

\begin{tabular}{lc}
\hline Ingredients & Quality (g/kg) Catfish feed (30\% protein) \\
\hline Fish Meal $(65 \% \mathrm{cp})$ & 150 \\
Soybean meal $(45 \% \mathrm{cp})$ & 450 \\
Maize & 250 \\
Blood Meal (85 percent cp) & - \\
Fish Oil & 40 \\
Vegetable oil & 60 \\
Vitamin/mineral premix & 0 \\
Binder & 20 \\
\hline
\end{tabular}

Source: Fagbenro and Adebayo (2005)

- Final mean weight $(\mathrm{g} /$ fish $)=$ Final harvested weight $(\mathrm{g})$ Number of fish harvested

- Mean Daily weight Gain (mg/day) = Final mean body weight (g)-Initial mean body weight(g) Duration of rearing period (day)

- Weight gain $=$ Final weight - Initial weight

- Food Conversion Ratio $=$ Total weight of Feed Total Weight of fish produce

- Specific Growth Rate $S G R==\underline{\operatorname{Ln} W_{2}-\operatorname{Ln} w_{1}} \times \underline{100}$ $\mathrm{T}_{2}-\mathrm{T}_{1} \quad 1$

(Jobling, 1994; Cui and Xie 2000; Alanara et al., 2001)

- Survival $(\%)=\underline{\text { Number of harvested fish }} \times \underline{100}$ Number of stocked fish 1

(Alatise and Otubusin, 2006)

- Fish yield $\left(\mathrm{kg} / \mathrm{m}^{2}\right)=\underline{\text { Total weight of fish }}$ Area of tank

(Jobling, 1994; Cui and Xie 2000; Alanara et al., 2001)

The economic evaluations of the fish were calculated by the following methods

1. Profit Index $=\underline{\text { Total value of fish USD }}$ Cost of feeding type

2. Net Production Value (NPV) NPV =Mean Weight gain of fish $(\mathrm{g}) \times$ Total survival (n) $X$ Cost per kg USD

3. Investment Cost Analysis (ICA) ICA = Cost of feeding USD + Cost of fry Stocked USD

4. Gross Profit (GP) GP $=$ NPV USD - ICA USD

5. Incidence of Cost (USD $/ \mathrm{kg})=$ Cost of feeding type USD $\mathrm{Kg}$ weight of fish produces

6. Benefit Cost Ratio $(B C R)=$ Total sales Total expenditure

(New, 1989; Aderolu and Oyedokun, 2008).

The data collected were analysed by one-way analysis of Variance (ANOVA) at $95 \%$ confidence level using SPSS (version 22) as described by Steel and Torrie (1980). Comparisons among means were separated using Duncan Multiple Range Test (DMRT) at $\mathrm{P}<0.05$.

\section{Results}

The mean values of water quality parameters measured in the three culture enclosures (plastic tank, sandcrete tank and earthen pond) are summarized in Table 2. It was observed that the parameters were similar for the three culture facilities this might be because the experiment was conducted in the same environment with the same source of water and also by changing the water on a weekly basis. This implies that changes in the yield and profit could not be attributed to water parameter. The water quality parameters measured in the three culture enclosures (plastic, sandcrete tanks and earthen pond) during the experimental period varied as follows: temperature (26.1- 27.1, 26.3-26.5 and 27.4-27.6), dissolved oxygen (6.30-6.63, 6.21-6.47 and 6.32-6.63), pH (7.13 -7.31, 7.10-7.19 and 7.02-7.05), Nitrite (0.22-0.23, 0.22-0.24 and 0.22-0.23), Nitrate (32.1-34.7, 31.7-34.2 and 29.130.9) respectively.

Table 3 shows the summary of the results obtained from the growth performance and fish yield of Oreochromis niloticus reared in plastic, sandcrete tanks and earthen pond. The result showed significant differences $(P<0.05)$ in the final mean weight, mean daily weight gain, specific growth rate (SGR), weight gain (WG), and feed conversion ratio in the three culture enclosures. The growth of $O$. niloticus reared in earthen pond had the highest final weight gain, mean daily weight gain and specific growth rate $(144.3 \pm 1.45$, $0.73 \pm 0.01$ and $1.54 \pm 0.01$ ) respectively.

The weight gains of $O$. niloticus reared in plastic tank, sandcrete tank and earthen pond is presented in Figure 1.

In sandcrete and plastic tanks, observed growth parameters (final mean weight, mean daily weight gain, specific growth rate and weight gain) had the following values; $127.7 \pm 2.03$ and $126.2 \pm 0.99,0.65 \pm 0.01$ and $0.64 \pm 0.01,1.48 \pm 0.01$ and $1.46 \pm 0.0,119.4 \pm 2.05$ and $117.8 \pm 0.96$ respectively. There was no significant difference $(P>0.05)$ in survival and feed intake of plastic and sandcrete tanks enclosures. $O$. niloticus reared in earthen pond had higher survival percentage of 
Table 2. Water Quality Parameters of the Three Culture Enclosures

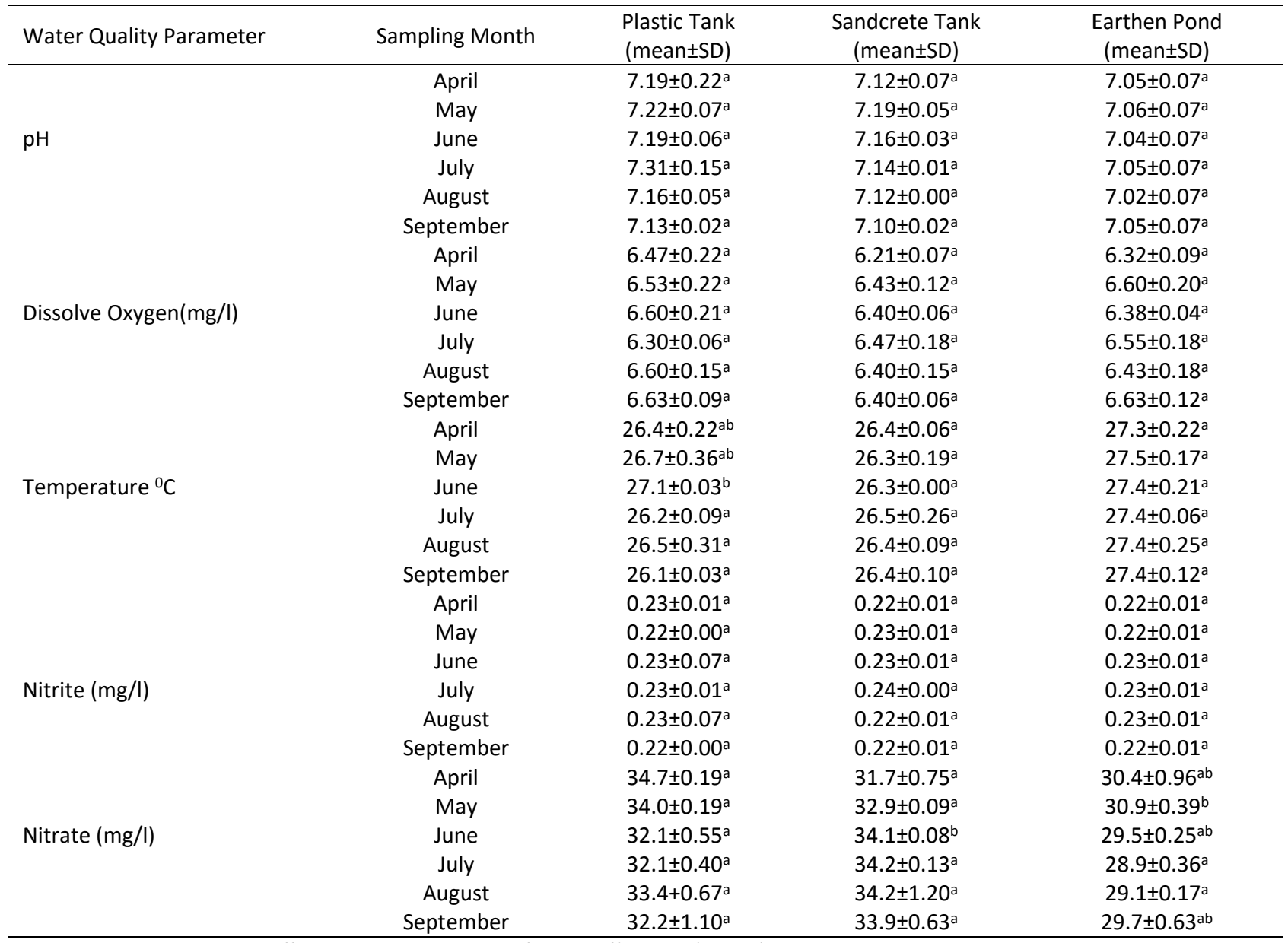

Means in the same row with different superscript, are significantly different at $(\mathrm{P}<0.05)$

Table 3. Growth Performance and fish yield of Oreochromis niloticus Reared in Plastic Tank, Sandcrete Tank and Earthen Pond

\begin{tabular}{|c|c|c|c|}
\hline Parameters & Plastic Tank (mean \pm SD) & Sandcrete Tank (mean \pm SD) & Earthen Pond (mean \pm SD) \\
\hline Initial mean weight(g) & $8.45 \pm 0.04^{a}$ & $8.30 \pm 0.06^{\mathrm{a}}$ & $8.40 \pm 0.06^{\mathrm{a}}$ \\
\hline Final Mean Weight(g) & $126.2 \pm 0.99^{a}$ & $127.7 \pm 2.03^{\mathrm{a}}$ & $144.3 \pm 1.45^{\mathrm{b}}$ \\
\hline Weight Gain(g) & $117.8 \pm 0.96^{a}$ & $119.4 \pm 2.05^{\mathrm{a}}$ & $135.9 \pm 1.49^{b}$ \\
\hline Mean Daily Weight gain(g) & $0.64 \pm 0.07^{a}$ & $0.65 \pm 0.01^{\mathrm{a}}$ & $1.54 \pm 0.01^{b}$ \\
\hline SGR (\%/day) & $1.46 \pm 0.00^{a}$ & $1.48 \pm 0.01^{\mathrm{a}}$ & $1.54 \pm 0.01^{b}$ \\
\hline Feed Intake (g) & $155.6 \pm 0.95^{a}$ & $156.0 \pm 1.89^{a}$ & $167.7 \pm 2.47^{b}$ \\
\hline FCR & $1.32 \pm 0.02^{b}$ & $1.31 \pm 0.01^{\mathrm{b}}$ & $1.23 \pm 0.03^{a}$ \\
\hline Survival (\%) & $88.7 \pm 0.67^{a}$ & $88.7 \pm 2.40^{\mathrm{a}}$ & $99.3 \pm 0.67^{b}$ \\
\hline Fish yield $\left(\mathrm{kg} / \mathrm{m}^{2}\right)$ & $1.42 \pm 0.07^{\mathrm{a}}$ & $1.47 \pm 0.01^{\mathrm{a}}$ & $1.93 \pm 0.05^{b}$ \\
\hline
\end{tabular}

Means in the same row with different superscript, are significantly different at $(\mathrm{P}<0.05)$

$99.3 \pm 0.67$ than that of sandcrete and plastic $88.7 \pm 2.40$ and $88.7 \pm 0.67$ respectively. The feed conversion ratio of 0 . niloticus from the three enclosure were significantly different $(P<0.05)$. However, the best feed conversion ratio $(F C R)$ was recorded in earthen pond $(1.23 \pm 0.030)$ followed by sandcrete tank $(1.31 \pm 0.01)$ and $1.32 \pm 0.02$ for plastic tank. Fish yield of $O$. niloticus reared in the three enclosure system showed significant difference $(\mathrm{P}<0.05)$. However, 0 . niloticus reared in the earthen pond had the highest yield value of 1.93, while sandcrete tank had 1.47 and plastic tank had the lowest value of 1.42 .
Table 4 shows the summary of profitability investment analysis of $O$. niloticus from the three culture enclosures, T1 (Plastic), T2 (Sandcrete) and T3 (Earthen Pond). The result revealed that total expenditure and gross income from plastic and sandcrete culture enclosures are not significantly different $(P>0.05)$ from each other. However, there was significant difference $(P<0.05)$ in the gross income and profit Margin of $O$. niloticus reared in the three culture enclosures, with $O$. niloticus reared in earthen pond having the highest profit margin of USD 4.77, compared to sandcrete and plastic tank that had the lowest value 


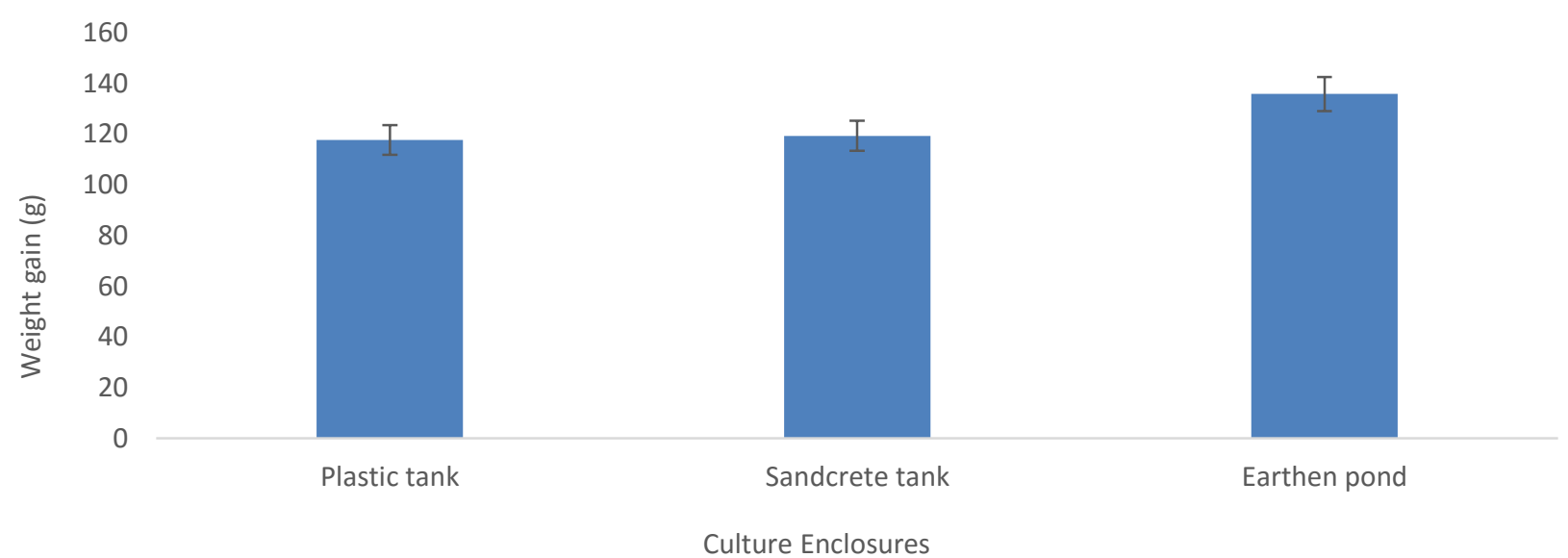

Figure 1. Weight gain of Oreochromis niloticus reared in three culture enclosures (plastic, sandcrete tanks and earthen pond)

of USD 0.44 and USD0.28, respectively. The value recorded for the profit margin of $O$. niloticus reared in plastic tank, sandcrete tank and earthen pond is presented in Figure 2.

Table 5 shows the summary of the economic performance parameters (Profit index, Net Production Values, Investment cost Analysis, Gross Profit, Incidence of Cost and Benefit Cost Ratio) of $O$. niloticus reared in the three culture enclosures T1 (Plastic), T2 (Sandcrete) and T3 (Earthen Pond). The result reveals that 0 . niloticus reared in earthen pond had the highest profit index ratio of $0.007 \mathrm{USD} / \mathrm{kg}$, while sandcrete had $0.005 \mathrm{USD} / \mathrm{kg}$ and plastic tank had the lowest ratio of $0.005 \mathrm{USD} / \mathrm{kg}$.

There was no significant difference $(P>0.05)$ between the benefit cost ratio, incidence of cost of $O$. niloticus reared in sandcrete tank and plastic tank (1.03 and 1.02, 265.4 and 268.1). However, O. niloticus reared in earthen pond enclosure had the highest benefit cost ratio of (1.31). The result also revealed that, 0 . niloticus reared in earthen pond had the lowest incidence of cost (209.3), sandcrete and plastic tank had the highest incidence of cost value 265.4 and 268.1, respectively.

\section{Discussion}

The values of temperature, $\mathrm{pH}, \mathrm{DO}$, nitrite and nitrate monitored during the experimental period (185days) were within acceptable ranges recorded by (Boyd, 1982) for fish culture practice. This factor probably enhanced the observed good growth and condition of the test fish throughout the experimental period.

Oreochromis niloticus fingerlings reared in the three culture enclosures revealed that there was steady increase in body weight of $O$. niloticus throughout the study period. However, $O$. niloticus fingerlings reared in earthen pond gained more weight than those reared in sandcrete and plastic tank (earthen $135.9 \mathrm{~g}$, sandcrete $119.4 \mathrm{~g}$ and plastic $117.8 \mathrm{~g})$. The superiority in growth performance shown by $O$. niloticus reared in earthen pond compared to sandcrete and plastic tanks in this present study is supported by the observation recorded by Ester, (2013) on comparative evaluation of growth performance and yield of four Tilapia species under culture conditions, the result is also supported by the observation recorded by Sorphen and Preston, (2001), on effect of processing pig manure in a bio digester as fertilizer input for pond growing fish in polyculture. However, the observed results on final weight in the current study are higher than the one reported by Rojas and Verreth, (2003) for the Tilapia fed on coffee pulp (45g); Hossain et al. (2003) who used aquaria systems (56.76g); Neves et al. (2008) in concrete tanks (48.77g), Zaki et al. (2010) in fibre glass tank (49.33g), Saad, et al. (2014) in earthen pond and Emmanuel et al. (2014) in out-door hapas.

Although the same quality of feed was given to $O$. niloticus reared in the three culture enclosures, the variation in growth performances of $O$. niloticus in earthen pond to sandcrete and plastic tanks could be attributed to the availability of natural food (plankton) induced by decomposed and degraded uneaten artificial feed given to $O$. niloticus in earthen pond to consume. In the tank facilities, the fish relied solely on artificial feed as the only food source. Despite the higher fish weight gained notices in the earthen pond, the percentage survival of earthen pond was also higher than that of the sandcrete and plastic tanks, this agrees with the reports of Saad et al. (2014) on growth and economic performance of $\mathrm{O}$. niloticus in fertilized earthen ponds.

The fish yield values obtained in the present study showed variation in $O$. niloticus reared in plastic tank, sandcrete tank and earthen pond. The fish yield from the three enclosure system showed that earthen pond enclosure system had the highest value of 1.93 , while sandcrete tank had 1.47 and plastic tank 1.42, respectively. This result also agrees with Saad et al. (2014) on growth performance of $O$. niloticus in fertilized earthen pond.

The adequate performance of any production system, evaluating the profit viability is expected to be done at the end of such production. It will become clear 
Table 4. Profit Analysis of Oreochromis niloticus Reared in Three Culture Enclosures (Plastic Tank, Sandcrete Tank and Earthen Pond)

\begin{tabular}{lccc}
\hline Parameters & Plastic Tank (mean \pm SD) & $\begin{array}{c}\text { SandcreteTank } \\
\text { (mean } \pm \text { SD) }\end{array}$ & $\begin{array}{c}\text { Earthen Pond } \\
\text { (mean } \pm S D)\end{array}$ \\
\hline Cost of fingerlings at (USD)0.04 each & $4.29 \pm 0.00^{\mathrm{a}}$ & $4.29 \pm 0.00^{\mathrm{a}}$ & $4.29 \pm 0.00^{\mathrm{a}}$ \\
Number of Fish stocked & $100.0 \pm 0.00^{\mathrm{a}}$ & $100.0 \pm 0.00^{\mathrm{a}}$ & $100.0 \pm 0.00^{\mathrm{a}}$ \\
Cost of locally made feed at & $8.57 \pm 0.00^{\mathrm{a}}$ & $8.57 \pm 0.00^{\mathrm{a}}$ & $8.57 \pm 0.00^{\mathrm{a}}$ \\
(USD)8.57(15kg/bag) & & & \\
Cost of Labour (USD) & $1.43 \pm 0.00^{\mathrm{a}}$ & $1.43 \pm 0.00^{\mathrm{a}}$ & $1.43 \pm 0.00$ \\
Cost of changing water (USD) & $1.43 \pm 0.00^{\mathrm{a}}$ & $1.43 \pm 0.00^{\mathrm{a}}$ & $1.43 \pm 0.00^{\mathrm{a}}$ \\
Percentage of fish harvested & $88 \pm 0.67^{\mathrm{a}}$ & $88 \pm 2.40^{\mathrm{a}}$ & $99 \pm 0.00^{\mathrm{a}}$ \\
Average weight of fish at harvest (g) & $0.126 \pm 0.00^{\mathrm{a}}$ & $0.127 \pm 0.16^{\mathrm{a}}$ & $0.144 \pm 0.00^{\mathrm{b}}$ \\
Total weight of fish cropped (kg) & $11.2 \pm 0.17^{\mathrm{a}}$ & $11.3 \pm 0.16^{\mathrm{a}}$ & $14.3 \pm 0.23^{\mathrm{b}}$ \\
Mortality recorded & $12.00 \pm 0.00^{\mathrm{a}}$ & $11.3 \pm 0.00^{\mathrm{a}}$ & $0.7 \pm 0.00^{\mathrm{a}}$ \\
Number of bags of feed consumed(15kg/bag) & $1.50 \pm 0.00^{\mathrm{a}}$ & $1.50 \pm 0.00^{\mathrm{a}}$ & $1.50 \pm 0.00^{\mathrm{a}}$ \\
Kilogram of Feed fed (kg) & $22.5 \pm 0.00^{\mathrm{a}}$ & $22.5 \pm 0.00^{\mathrm{a}}$ & $22.5 \pm 0.00^{\mathrm{a}}$ \\
Total Expenditure (USD) & 15.71 & 15.71 & 15.71 \\
Gross Income (USD) & $15.99^{\mathrm{a}}$ & $16.16^{\mathrm{a}}$ & $20.48^{\mathrm{b}}$ \\
Profit margin (Gross margin) (USD) & $0.28^{\mathrm{a}}$ & $0.44^{\mathrm{b}}$ & $4.77^{\mathrm{c}}$ \\
\hline
\end{tabular}

Means in the same row with different superscript are significantly different at $(\mathrm{P}<0.05)$

Table 5. Economic Performance of Oreochromis niloticus Reared in Three Culture Enclosures (Plastic Tank, Sandcrete Tank and Earthen Pond)

\begin{tabular}{lccc}
\hline Parameters & Plastic Tank (mean \pm SD) & $\begin{array}{c}\text { Sandcrete Tank } \\
\text { (mean } \pm \text { SD) }\end{array}$ & Earthen Pond (mean \pm SD) \\
\hline Profit Index & $0.005 \pm 0.03^{\mathrm{a}}$ & $0.005 \pm 0.03^{\mathrm{a}}$ & $0.007 \pm 0.04^{\mathrm{b}}$ \\
Net Production Value (USD) & $15.99 \pm 86.2^{\mathrm{a}}$ & $16.16 \pm 78.4^{\mathrm{a}}$ & $20.48 \pm 114.2^{\mathrm{b}}$ \\
Investment Cost Analysis (USD) & $15.71 \pm 0.00^{\mathrm{a}}$ & $15.71 \pm 0.00^{\mathrm{a}}$ & $15.71 \pm 0.00^{\mathrm{a}}$ \\
Gross Profit (USD) & $0.28 \pm 40.7^{\mathrm{b}}$ & $0.44 \pm 3.71^{\mathrm{b}}$ & $4.77 \pm 3.36^{\mathrm{a}}$ \\
Incidence of Cost & $1.02 \pm 0.02^{\mathrm{a}}$ & $1.03 \pm 0.02^{\mathrm{a}}$ & $1.31 \pm 0.02^{\mathrm{b}}$ \\
Benefit Cost Ratio & $1.86 \pm 0.03^{\mathrm{a}}$ & $1.88 \pm 0.03^{\mathrm{a}}$ & $2.39 \pm 0.04^{\mathrm{b}}$ \\
\hline
\end{tabular}

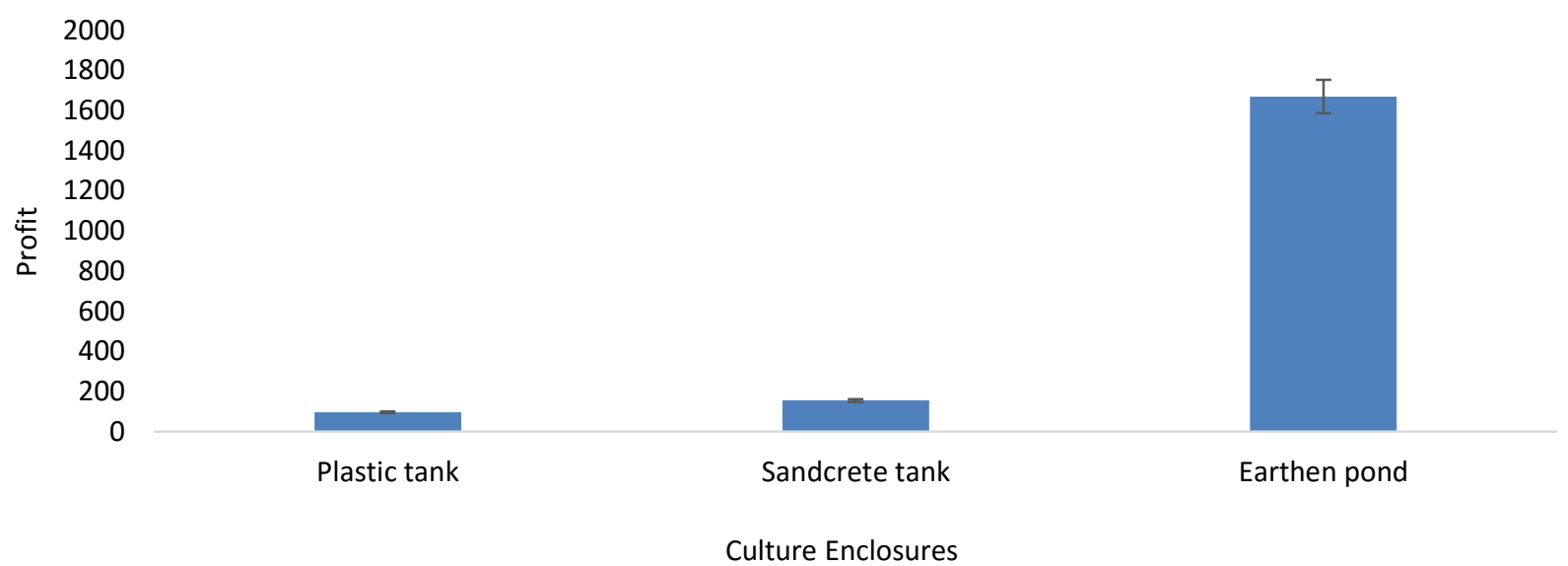

Figure 2. Profit margin of Oreochromis niloticus reared in three culture enclosures (plastic tank, sandcrete tank and earthen pond)

if such production system is profitable or not (Ross and Waten, 1995). The profit margin recorded for 0 . niloticus reared in earthen pond enclosure system in this present study had the highest value of (USD4.77) compared to $O$. niloticus reared in Sandcrete and Plastic that had the value of (USD0.44 and USD0.28), this was in accordance with the report of Egware and Orewa, (2013) on comparatives profit analysis of Catfish. The profit margin for earthen pond was higher with its higher fish survival. The earthen pond structure, though a confined enclosure as the plastic and sandcrete tanks facilities, mimic nature and this may be responsible for its high yield in terms of fish size.

The economic parameters observed for $O$. niloticus in this present study revealed that profit index, net production value, investment cost analysis, and benefit cost ratio value of sandcrete and plastic tank system were lower and similar (not significantly difference $(P>0.05)$. However earthen pond enclosure system had the highest value/ratio of profit index, net production 
value, gross profit, and benefit cost ratio, indicating that earthen pond production system is an efficient system of producing $O$. niloticus than sandcrete and plastic tanks. This result is in agreement with the one reported by Ajani et al. (2015) on growth and economic performance of Clarias gariepinus. The result on profit index indicates that earthen pond had the highest profit ratio to the production cost $(0.007 \$ 0.003 / \mathrm{kg})$ than sandcrete and plastic tank. This is due to the fact that the incidence of cost of $O$. niloticus reared in earthen pond is the least (\$0.598).

\section{Conclusion}

The results from this study show that the impact of fish rearing enclosure systems cannot be overemphasized on the overall performance result of fish production. The three culture enclosures used in this study are suitable for $O$. niloticus production. Profitability from the production of fish is a function of the final weight gain and the fish survival which in turn is dependent on knowledge in fish production and the application of the technical management practice acquired by the farmer/ investor. However, for viable production and profitability of $O$. niloticus, earthen pond culture enclosures are the best and the most ideal culture facility for optimum yield of $O$. niloticus.

\section{Acknowledgements}

I am extremely grateful to the Head of Department of Fisheries and Aquaculture Technology, Federal University of Technology, Akure, Ondo State, for providing facilities for carrying out the investigation. The authors thank Mr Mike Ojuola for technical assistance during the study

\section{References}

Adekoya, B.B. \& Miller, J.W. (2004). Fish cage culture potential in Nigeria- An Overview National cultures. Agricultural focus, 1(5): 10

Aderolu, A.Z. \& Oyedokun, G.T. (2008). Comparative utilization of biodegraded rice husk in the diets of Clarias gariepinus. Journal of Fisheries and Aquatic Science, 3(5): 312-319.

Adewolu, M.A. (2008). Potentials of sweet potato (Ipomoea batatas) leaf meal as dietary ingredient for Tilapia zillii fingerlings. Pakistan Journal of Nutrition. 7(3): 444- 449.

Ajani, E. K., Orisasona, O., \& Jenyo-Oni, A. (2015). Growth and economic performance of Clarias gariepinus fry reared at various stocking densities. Journal of Fisheries Livestock Production. 3:136 - 141

Alanara, A., Kaaris, S., \& Paspatis, M. (2001). Feeding management. In: Hoalihan D, Jobling M, Boujard, T. Feed intake in Fish. Oxford, UK: Black well Science. pp 332-353

Alatise, S.P. \& Otubusin, S.O. (2006). Effect of different stocking densities on production of Catfish (Clarias gariepinus) in Bamboo-net cage System. Conference of FISON at Port Harcourt, pp 24-29

Angahar, L.T. (2017). Comparative Studies on Growth
Performance of Heterobrancus bidorsalis (Geoffroy Saint-Hilaire, 1809) in Different Culture Facilities. Turkish Journal of Agriculture Food Science and Technology, 5(3): 247-250

Boyd, C.E. (1982). Water Quality Management for pond fish culture/ Elsevier Scientific Publication Company. New York, 318pp.

Chakraborty, S. B. \& Banerjee, S. (2012). Comparative growth performance of mixed-sex and monosex Nile tilapia at various stocking densities during cage culture. Recent Research in Science and Technology. 4: 46-50.

Cui, Y. \& Xie, S. (2000). Modeling growth in fish. In: Theodorou, M.K and France, J (Eds). Feeding systems and feed evaluation models. $C A B$ International. pp 413-434

Dagne, A., Degefu, F., \& Lakew, A. (2013). Comparative growth performance of mono-sex and mixed-sex Nile tilapia (Oreochromis niloticus L.) in pond culture system at Sebeta, Ethiopia. International Journal of Aquaculture. 3: 30-34.

Egware, R. A. \& Orewa, S. I. (2013). A Comparative profit analysis of Catfish (Clarias gariepinus) production in Ughelli, Delta State, Nigeria. International Journal of African and Asian Studies. 1: 1-3.

El-Sayed, A. F. M. (2006). Tilapia culture. Wallingford, Oxfordshire, UK, CABI Publishing. pp. 1- 45.

Emmanuel, T.D.M., Felix, K.Y.A., \& Ken, A. (2014). Comparative growth study of Oreochromis niloticus and Sarotherodon galilaeus under two different culture regimes (Hapa-InPond and cage systems). International Journal Fisheries Aquatic Studies. 1: 53-59

Ester, E.M. (2013). Comparative evaluation of growth performance and yield of four tilapia species under culture conditions. (Master's Thesis) Sokoine University of Agriculture. pp 1-83

Fagbenro, O.A. \& Adebayo, O.T. (2005). A review of the animal and aqua feed industries in Nigeria. In: A synthesis of the formulated animal and industry in sub-Saharan Africa (John Moehl and Mathias Halwart, eds.) FAO/CIFA Occasional Fisheries Technical Paper, No.26, FAO, Rome. pp $25-36$.

FAO, (2012). The State of World Fisheries and Aquaculture. In: 2011, FAO of the United Nations, Rome. pp 209.

FAO, (2013). Fish Trade and Human Nutrition. Rome. Food and Agriculture Organization of the United Nation Press. pp 49

FAO, (2018). State of World Fisheries and Aquaculture Report. 2018 edition, Food and Agriculture Organization of the United Nations, Rome, Italy. pp 14

Fitzsimmons, K. (2005). Tilapia culture. In: Kelly, A. M., Silverstein, J. (eds), Aquaculture in the 21st Century: American Fisheries Society; Symposium 46, Bethesda, Maryland, pp. 563-590.

Hernandez, M., Gasca-Leyva, E., \& Milstein, A. (2013). Polyculture of mixed-sex and male populations of Nile tilapia (Oreochromis niloticus) with the Mayan cichlid (Cichlasoma urophthalmus). Aquaculture. 1: 418- 419.

Hossain, M. A., Folken, U., \& Becker, K. (2003). Nutritional evaluation of dhaincha (Sesbania aculeate) seeds as dietary protein source for tilapia, Oreochromis niloticus. Aquaculture Research. 33: 653-662.

Jobling, M., (1994). Biotic factors and growth performances. In: Fish Bioenergetics, Fish and Fisheries series 13. Chapman and Hall. pp. 169-194

Liti, D., Cherop, L., Mungitti, J., \& Chhorn, L. (2005). Growth and economic performance of Nile tilapia (Oreochromis 
niloticus) fed on two formulated diets and two locally available feeds in fertilized ponds. Aquaculture Resource. 36: 746-752.

Neves, P. R., Ribeiro, R. P., Vargas, L., Natali, M. R. M., Maehana, K. R., \& Marengoni, N. G. (2008). Evaluation of performance of two strains of Nile tilapia in Mixed Raising Systems. Brazilian Archives of Biology and Technology. 51: $531-538$.

New, M.B. (1989). Formulated Aquaculture Feeds in Asia: Some Thoughts on Comparative Economics, Industrial Potential, Problems and Research Need in Relation to Small-Scale Farmer. In Report of the Work-shop on Shrimps and Fin Fish Feed Development, J.E. Bahru, (Ed.) ASEAN/SF/89/GGEN/11. pp. 112-115

Nwokoye, C.O., Nwuba, L.A., \& Eyo, J.E. (2007). Induced propagation of African Clariid Catfish Heterobranchus bidorsalis (Geoffrey Saint Hillarie 1809), using synthetic and homoplastic hormones. African Journal of Biotechnology. 6(23): 2687-2693

Ogello, E.O., Musa, S., Aura, C. M., Abwao, J. O. \& Munguti, J. (2014). A critical appraisal of feasibility of tilapia production in earthen ponds using biofloc technology, a review. International Journal of aquatic sciences. 5:2139.

Olaoye, O., Adegbite, D., Elizabeth, O., Vaugh, I., Odebiyi, C. \& Adediji, A. (2014). Comparative evaluation of economic benefits of earthen fish and concrete ponds in aquaculture enterprises in Oyo State, Nigeria. Croatian Journal of fisheries.72 (3):107-119.

Omitoyin, B.O. (2007). Plasma Biochemical Changes in Clarias gariepinus (Burchell, 1822) Fed Poultry Litter. Asian Journal of Animal Sciences. 1: 48-52.

Osawe, M. (2007). Technical know-how of Catfish Growout for Table size in 4 - 6 months. Proceedings of Seminar on Modern Fish Farming by Dynamo Catfish Production, Lagos. pp. 1-14.

Rojas, J. B. U. \& Verreth, J. A. J. (2003). Growth of Oreochromis aureus fed with diets containing graded levels of coffee pulp and reared in two culture systems. Aquaculture. 217: $275-283$.

Ross, R.M. \& Waten, B.J. (1995). Importance of Rearing - Unit Design and Stocking density to the Behaviour, growth and Metabolism of lake trout (salvelinus namaysuch) Aquaculture Engineering. pp. 40-45.

Saad, T. T., El-Hawarry, W. N., \& Abel-lateef, M. A., (2014). Growth and economic Performance of oreochromis niloticus in fertilized earthen ponds. Journal of Middle East Applied Science and Technology. 2(4): 463-475

Siddik, M. A. B., Nahar, A., Ahamed, F., \& Hossain, M.Y. (2014). Over-wintering growth performance of mixed-sex and mono-sex Nile tilapia Oreochromis niloticus in Northeastern Bangladesh. Croatian Journal of Fisheries. 72: $70-76$.

Sorphen, P. \& Preston, T. R. (2001). Effect of processing pig manure in a biodigester as fertilizer input for ponds growing fish in polyculture. Livestock Research for Rural Development. 13: 1 - 14.

Steel, R. G. D. \& Torrie, J. H. (1980). Principles and procedures of statistics: A biometrical approach. McGraw Hill Book Company, New York. pp. 101-123.

Tijani, A. (2004). Comparative analysis of profitability and technical efficiency of fish farming using different rearing techniques in Nigeria. Assian Journal of Agricultural Extension, Economics and Sociology. 3(5):405-418.

Tsadik, G. G., \& Bart, A. N. (2007). Effects of feeding, stocking density and water-flow rate on fecundity, spawning frequency and egg quality of Nile tilapia, Oreochromis niloticus (L.). Aquaculture. 272: 380-388.

World Fish Centre (2003). Fish an issue for everyone: A concept paper for fish for all Summit. pp. 10.

Zaki, M. I., Helal, A. M., Farrag, F. H., Khalil, F. F. M., \& Rafaey, M. M. A. (2010). Impact of different levels of dietary myo - inositol on the growth performance, histological structure of gonads and liver of red tilapia in brackish water. African Journal of Biotechnology. 9: 4808-4817 